\title{
Soil Fertility Mapping Using Soil Health Card data and Geospatial Technology in Ri Bhoi District of Meghalaya
}

Pratibha Thakuria Das*, Bipul Saikia, Tangwa Lakiang, Dharmendra Kumar Jha, Priyanka Longmailai, PLN Raju North Eastern Space Applications Centre, Department of Space, Govt. of India, Umiam, Meghalaya-793103, India

\begin{tabular}{|c|c|}
\hline $\begin{array}{c}\text { Article History } \\
\text { Received: } 02.11 .2020 \\
\text { Accepted: } 13.11 .2020 \\
\text { Published: } 17.11 .2020 \\
\text { Journal homepage: } \\
\text { http://www.easpublisher.com/easjals/ }\end{array}$ & $\begin{array}{l}\text { Abstract: Soil fertility maps namely } \mathrm{pH}, \mathrm{EC}, \mathrm{OC} \text { (Physical parameters); } \mathrm{P}, \mathrm{K} \text { (Macro } \\
\text { nutrients) and } \mathrm{Zn}, \mathrm{Fe}, \mathrm{Cu}, \mathrm{Mn} \text { (Micro nutrients) were generated using Geographic } \\
\text { Information System from grid wise soil health data. The study revealed that soils of Ri } \\
\text { Bhoi district is non saline with high organic carbon content. It is observed that soils of } \\
68.87 \% \text { area of the district are slightly acidic and } 26.22 \% \text { soils are moderately acidic in } \\
\text { nature. The availability of phosphorus is medium in } 73.93 \% \text { soils followed by high and } \\
\text { low phosphorus that covers } 14.16 \% \text { and } 11.91 \% \text { area respectively. The highest area } \\
\text { (i.e.66.49\%) of the district is having medium available potassium followed by high and } \\
\text { low potassium that covers } 19.97 \% \text { and } 13.60 \% \text { area respectively. The soils of the study } \\
\text { district are mostly rich in micronutrients and more than } 80 \% \text { areas are sufficient in } \\
\text { micronutrient contents. Only } 15.48 \% \text { area is deficient in zinc whereas iron, copper and } \\
\text { manganese is deficient in <1\%, } 1.02 \% \text { and } 6.06 \% \text { areas respectively. } \\
\text { Keywords: Soil fertility mapping, Soil Health Card, Geographic Information System, } \\
\text { Meghalaya. }\end{array}$ \\
\hline & \\
\hline
\end{tabular}

\section{INTRODUCTION}

The soil fertility evaluation is the most basic decision making tool for effective soil fertility management plan. Site specific nutrient management is the most advanced technique for effective soil fertility management that takes into account spatial variations in nutrients status, thus cutting down the possibility of over or under use of fertilizer. There are several techniques for the evaluation of soil fertility status. Among them soil testing is a most popular everywhere, as well as more appropriate also. Soil testing provides information regarding nutrient availability in soils which forms the basis for the fertilizer recommendations for economic production of crops [1]. Soil analysis includes physical properties (texture, structure, colour, bulk density etc.) and chemical properties (soil $\mathrm{pH}$, organic matter, macro and micronutrients etc.), which symbolize prerequisite for sustainable soil management [2]. Soil properties vary spatially from a small to larger area might be due to effect of intrinsic (parent materials and climate) and extrinsic factors such as soil management practices, indigenous fertility status, crop rotation and nature of standing crop [3]. Describing the spatial variability of soil fertility across a field has been difficult until new technologies such as Global Positioning Systems (GPS) and Geographic Information Systems (GIS) were introduced. Collection of soil samples by using GPS is very important for preparing thematic soil fertility maps [4]. Similarly, Geographical Information System (GIS) is a powerful tool used for easy access, retrieval and manipulation of voluminous data and derive spatial map based on soil sample analysis data collected from different locations. It facilitates manipulation of spatial and attributes data useful for handling multiple data of diverse origin [5]. Based on the geo-statistical analysis, several studies have been conducted to characterize the spatial variability of different soil properties [6-12]. Furthermore, GIS generated soil fertility maps may serve as a decision support tool for nutrient management [13].

Soil Health Management (SHM) is one of the most important interventions under National Mission for Sustainable Agriculture (NMSA) that aims at enhancing agricultural productivity especially in rainfed areas focusing on integrated farming. SHM aims at promoting Integrated Nutrient Management (INM) through judicious use of chemical fertilizers including secondary and micro nutrients in conjunction with organic manures and bio-fertilizers for improving soil health and its productivity. Soil Health Card (SHC) scheme is a Government of India's scheme promoted by the Department of Agriculture \& Co-operation under the Ministry of Agriculture. It is being implemented through the Department of Agriculture of all the State 
and Union Territory Governments. A SHC is meant to give each farmer soil nutrient status of his holding and advice him on the dosage of fertilizers and also the needed soil amendments, that he should apply to maintain soil health in the long run. The SHC gives the information for a particular location (latitude, longitude) which is collected by using GPS. If the farmers get maps showing spatial variability of nutrient status it will be more effective for site specific nutrient management. Therefore, Department of Agriculture \& Co-operation under the Ministry of Agriculture has instructed Department of Agriculture of all the State and Union Territory Governments to generate village level fertility map. In this background, Directorate of Agriculture, Govt. of Meghalaya has entrusted North Eastern Space Applications Centre (NESAC) to generate soil fertility map by using Soil Health Card data.

\section{Materials ANd Methodology}

For preparation of soil fertility map of Ri Bhoi district, soil health data has been collected from SHC portal https//soilhealth.dac.gov.in. From the soil health card dashboard, grid wise soil health data has been downloaded for the entire district. The downloaded data is edited in Microsoft excel and brought to GIS environment compatible format. Then one point layer is generated by using soil sample location (latitude, longitude) information under GIS environment using ArcGIS 10.3 software. The point layer contains soil sample numbers, village name and soil sample analysis results. It has been found that in the SHC portal only 9 parameters are available for $\mathrm{Ri}$-Bhoi district. The available nine parameters are $\mathrm{pH}, \mathrm{EC}, \mathrm{OC}$ (Physical parameters); P, K (Macro nutrients) and $\mathrm{Zn}, \mathrm{Fe}, \mathrm{Cu}, \mathrm{Mn}$ (Micro nutrients). These nine soil parameters have been used for generation of nine fertility maps. The fertility maps have been generated by using Spatial Analyst tools of ArcToolbox. Inverse Distance Weighted (IDW) interpolation technique has been applied to generate fertility map of unknown locations based on information of known locations. Block wise area statistics has been calculated. The detail of the methodology is illustrated in Figure1. The road network map has been prepared by using high resolution satellite imageries. It is found that in Meghalaya, village boundary map is not available. Therefore village location map has been prepared by using Soil Health Card data, Google map and Census data.

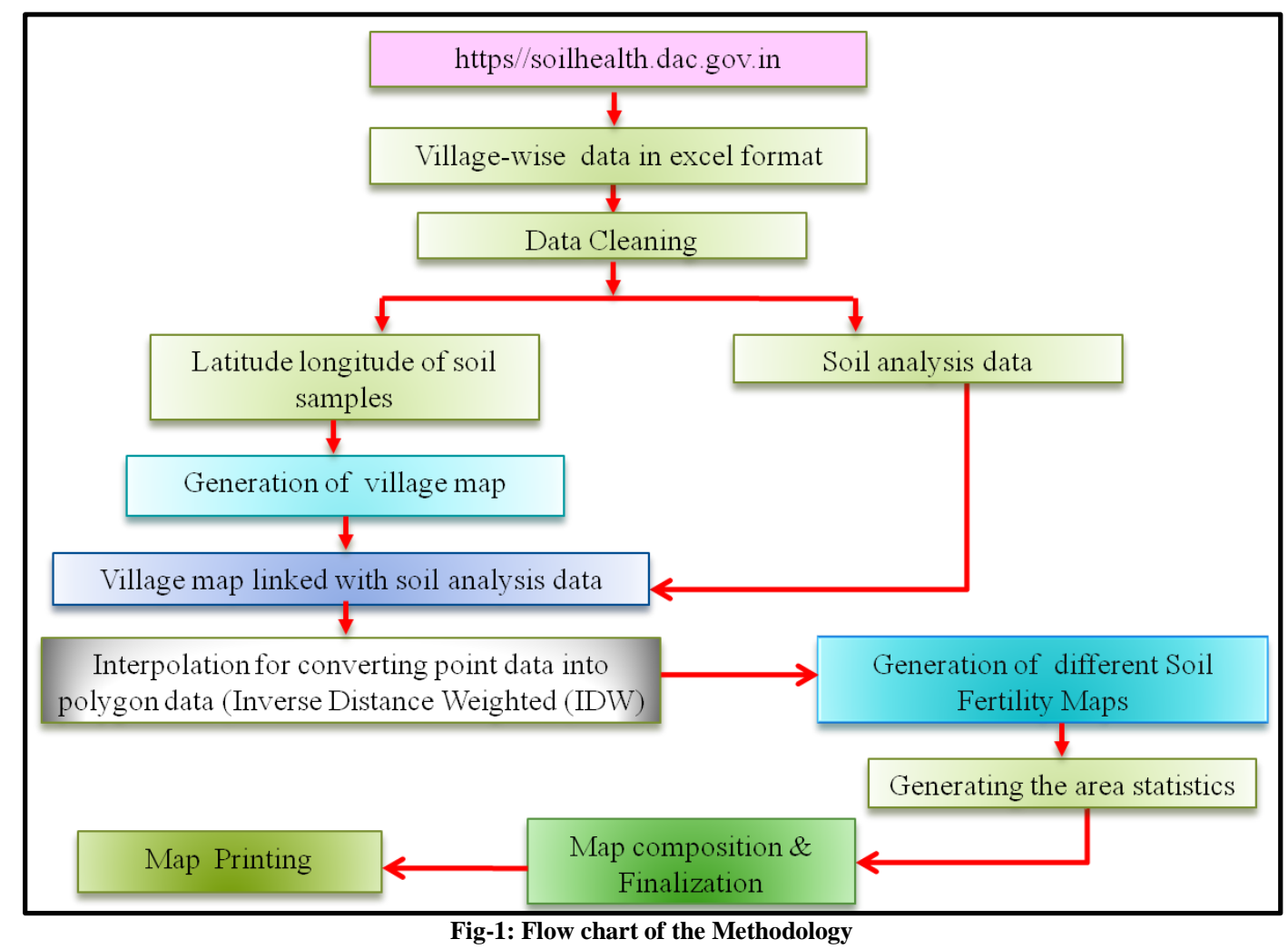

\section{RESULTS AND DISCUSSION}

Nine fertility maps namely $\mathrm{pH}, \mathrm{EC}, \mathrm{OC}$ (Physical parameters); P, K (Macro-nutrients) and Zn, $\mathrm{Fe}, \mathrm{Cu}, \mathrm{Mn}$ (Micro - nutrients) were generated for RiBhoi district of Meghalaya (Figure-2 and Figure-3). From the study, it is found that $95 \%$ soils of Ri-Bhoi district are acidic in nature. Only 5\% soils are neutral in soil $\mathrm{pH}$. It is observed that $68.87 \%$ soils of the district is slightly acidic (>5.5-6.5) in nature followed by moderately acidic (4.5-5.5) soil that covers $26.22 \%$ area. Negligible area i.e. only 8.36 ha area is found to be strongly acidic $(<4.5)$ in reaction. It has also been observed that electrical conductivity of soils of the 
district is $<1.68$ which is non saline. Ri-Bhoi district soils are rich in organic carbon and from the map it is found that $99 \%$ soils are having high $(>0.75 \%)$ organic carbon content. Only $0.84 \%$ soils of the district contain medium $(0.5-0.75 \%)$ organic carbon whereas the remaining soils contain low $(<0.5 \%)$ organic carbon. The availability of phosphorus in soils of Ri-Bhoi district varies from low to high. It is observed that $73.93 \%$ soils of the district is medium $(10-25 \mathrm{~kg} / \mathrm{ha})$ in available phosphorus followed by high $(>25 \mathrm{~kg} / \mathrm{ha})$ and low $(<10 \mathrm{~kg} / \mathrm{ha})$ phosphorus that covers $14.16 \%$ and $11.91 \%$ area respectively. The study showed that available potassium of soils varies from low to high. The highest area $(66.49 \%)$ of the district is having medium $(120-280 \mathrm{~kg} / \mathrm{ha})$ available potassium followed by High $(>280) \mathrm{kg} / \mathrm{ha}$ and Low $(<120 \mathrm{~kg} / \mathrm{ha})$ potassium that covers $19.97 \%$ and $13.60 \%$ area respectively. The soils of Ri-Bhoi district are mostly rich in micronutrients; it is observed that more than $80 \%$ areas are sufficient in micronutrient contents. Only $15.48 \%$ area is deficient in zinc whereas iron, copper and manganese is deficient in $<1 \%, 1.02 \%$ and $6.06 \%$ areas respectively (Table-1).

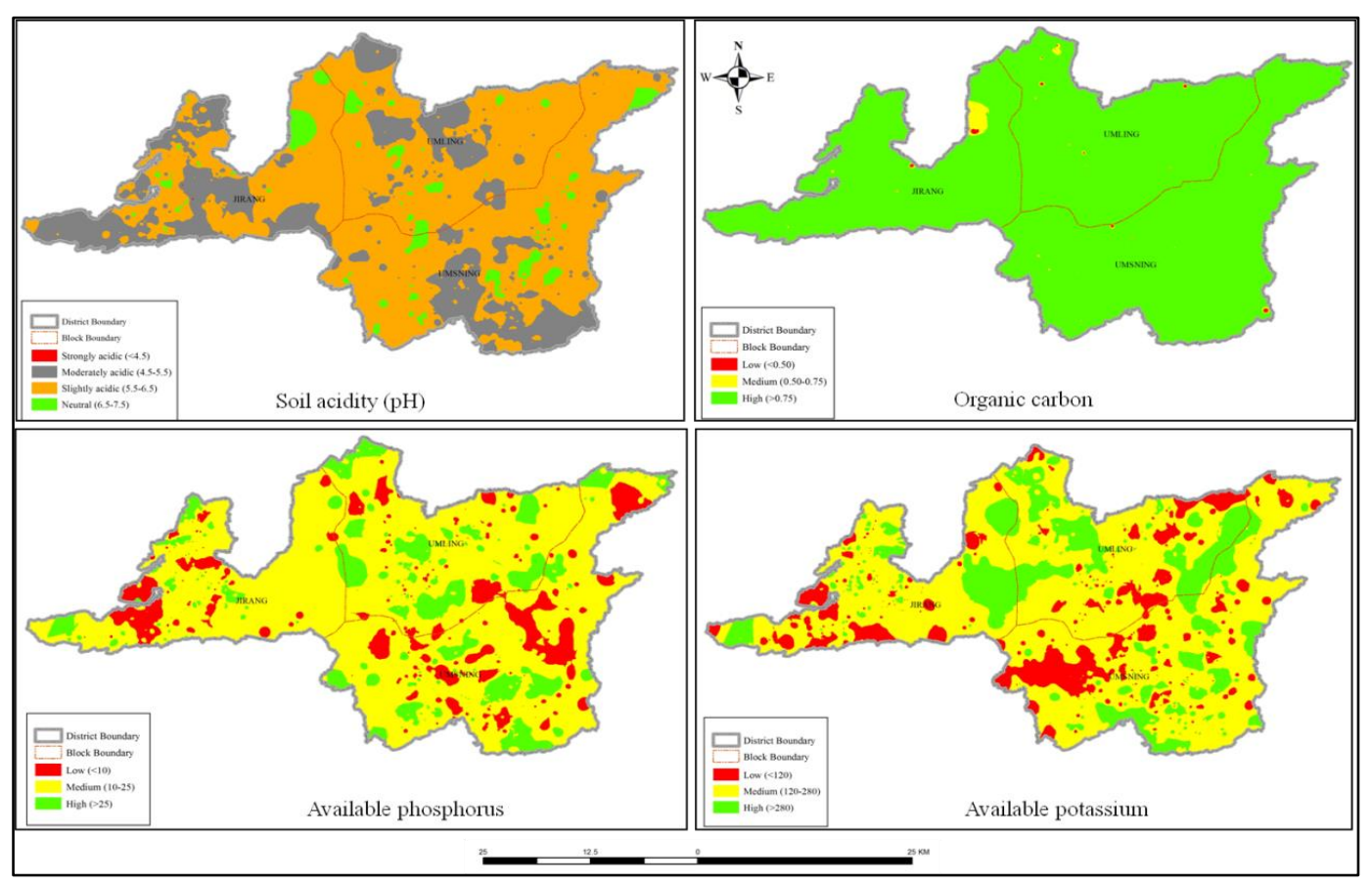

Fig-2: Spatial distribution of $\mathrm{pH}, \mathrm{OC}$, available $\mathrm{P}$ and $\mathrm{K}$ in $\mathrm{Ri}$ Bhoi district

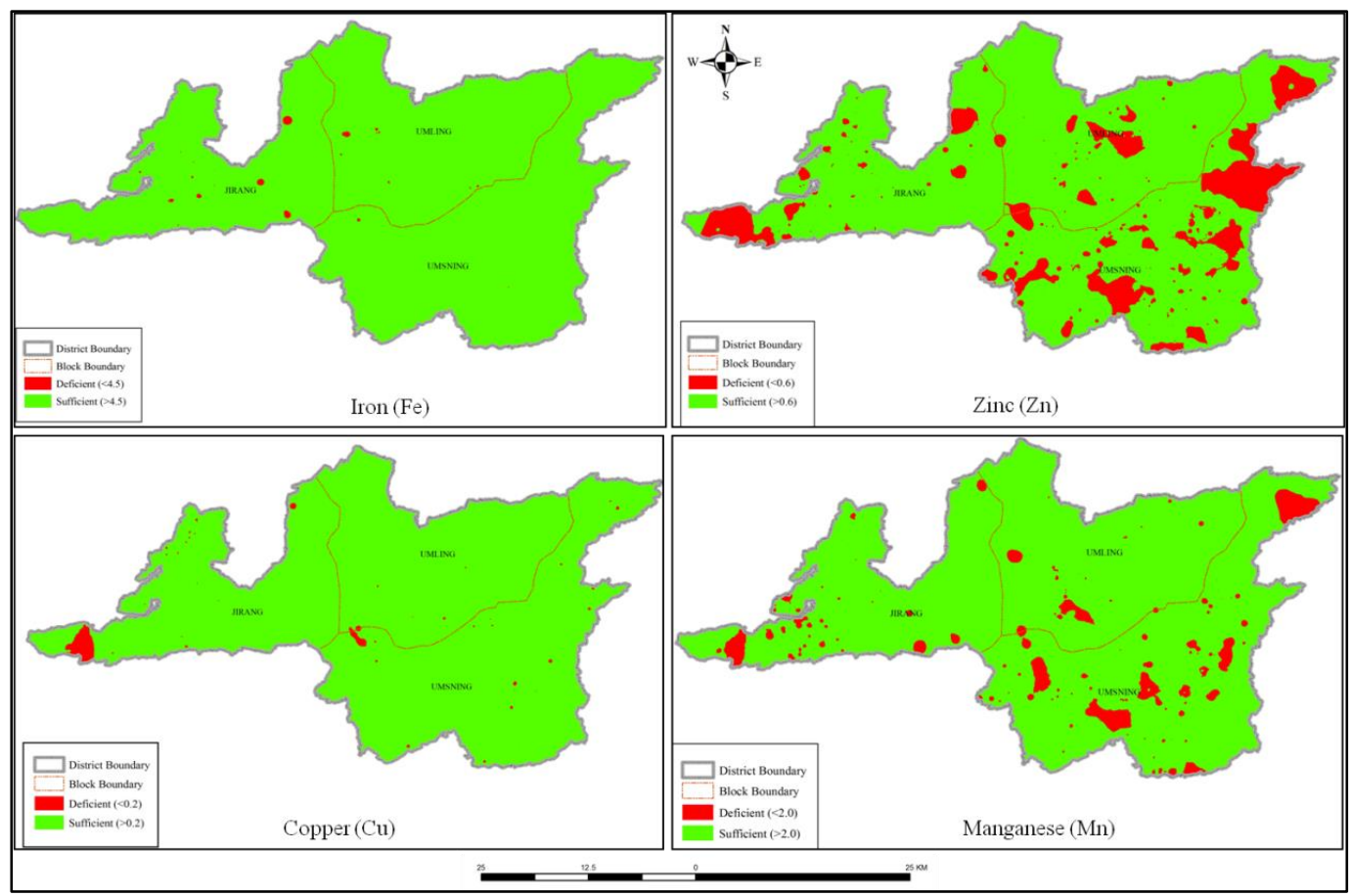

Fig-3: Spatial distribution of iron, zinc, copper and manganese in Ri Bhoi district 
Table-1: Area under different fertility classes of Ri-Bhoi district

\begin{tabular}{|c|c|c|c|c|c|c|c|c|c|}
\hline \multirow{8}{*}{ 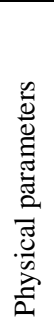 } & Parameters & Class & Area(ha) & Area $(\%)$ & \multirow{9}{*}{ 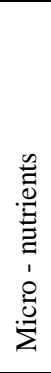 } & Parameters & Class & Area(ha) & Area $(\%)$ \\
\hline & \multirow{4}{*}{$\mathrm{pH}$} & Strongly acidic $(<4.5)$ & 8.36 & 0.00 & & \multirow{2}{*}{$\mathrm{ZN}(\mathrm{ppm})$} & Deficient $(<0.6)$ & 36529.03 & 15.48 \\
\hline & & $\begin{array}{l}\text { Moderately acidic (4.5- } \\
5.5)\end{array}$ & 61864.80 & 26.22 & & & Sufficient $(>0.6)$ & 199419.29 & 84.52 \\
\hline & & Slightly acidic $(>5.5-6.5)$ & 162504.69 & 68.87 & & \multirow[t]{2}{*}{$\mathrm{Fe}(\mathrm{ppm})$} & Deficient $(<4.5)$ & 612.28 & 0.26 \\
\hline & & Normal $(>6.5-7.3)$ & 11570.46 & 4.90 & & & Sufficient $(>4.5)$ & 235336.04 & 99.74 \\
\hline & \multirow[t]{3}{*}{$\mathrm{OC}(\%)$} & Low $(<0.50)$ & 229.03 & 0.10 & & \multirow[t]{2}{*}{$\mathrm{Cu}(\mathrm{ppm})$} & Deficient $(<0.2)$ & 2406.28 & 1.02 \\
\hline & & Medium (0.50-0.75) & 1977.88 & 0.84 & & & Sufficient $(>0.2)$ & 233542.03 & 98.98 \\
\hline & & High $(>0.75)$ & 233741.41 & 99.06 & & \multirow[t]{2}{*}{$\mathrm{MN}(\mathrm{ppm})$} & Deficient $(<2.0)$ & 14287.06 & 6.06 \\
\hline \multirow{6}{*}{ 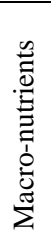 } & \multirow[t]{3}{*}{$\mathrm{P}(\mathrm{kg} / \mathrm{ha})$} & Low $(<10)$ & 28089.90 & 11.91 & & & Sufficient $(>2.0)$ & 221661.26 & 93.94 \\
\hline & & Medium (10-25) & 174442.01 & 73.93 & & & & & \\
\hline & & High $(>25)$ & 33416.40 & 14.16 & & & & & \\
\hline & \multirow[t]{3}{*}{$\mathrm{K}$ (kg/ha) } & Low $(<120)$ & 32083.26 & 13.60 & & & & & \\
\hline & & Medium (120-280) & 156886.98 & 66.49 & & & & & \\
\hline & & High $(>280)$ & 46978.07 & 19.91 & & & & & \\
\hline
\end{tabular}

From the block level map it is observed that organic carbon content of soil is high in $>90 \%$ areas and low in $<1 \%$ area of each block. Soils of Jirang block are mostly slightly acidic and moderately acidic that covers $56.38 \%$ and $38.78 \%$ area respectively. Soil acidity of Umling and Umsning block is also mostly slightly acidic that covers $>70 \%$ area where as moderately acidic soils occupy about $21 \%$ area. It is observed that about $80 \%$ soils of Jirang block is medium in available phosphorus. Medium available phosphorus is found in about $70 \%$ area of Umling and Umsning block. High available phosphorus is found highest in Umling block that covers $20.75 \%$ area followed by Umsning (13.80\%) and Jirang block (Figure-3 and Table-2). Soils of different blocks are medium in potassium content and it is observed that highest area is found in Umsning block followed by Jirang and Umling block. Sufficient micronutrients are available in the soils of all blocks of $\mathrm{Ri}$-Bhoi district that covers $94.14 \%, 87.95 \%$, and $75.39 \%$ area in Umling, Jirang and Umsning block respectively. It is observed that more than $99 \%$ soils of all blocks of the district are sufficient in Fe. Soils of all blocks are having sufficient $\mathrm{Cu}$ and highest area is found in Umling $(99.86 \%)$ block followed by Umsning $(99.48 \%)$ and Jirang $(97.28 \%)$ block. Soils of Umling block contains sufficient in $\mathrm{Mn}$ that covers $97.78 \%$ area followed by Jirang (95.13\%) and Umsning (90.44\%) block.

Table-2: Area under different fertility classes in blocks of Ri-Bhoi district

\begin{tabular}{|c|c|c|c|c|c|c|c|c|}
\hline & \multirow[t]{2}{*}{ Parameters } & \multirow{2}{*}{$\begin{array}{l}\text { Block name } \\
\text { Class }\end{array}$} & \multicolumn{2}{|l|}{ Jirang } & \multicolumn{2}{|l|}{ Umling } & \multicolumn{2}{|l|}{ Umsning } \\
\hline & & & Area(ha) & $\begin{array}{l}\% \\
\text { area }\end{array}$ & Area(ha) & $\begin{array}{l}\% \\
\text { area }\end{array}$ & Area(ha) & $\%$ area \\
\hline \multirow{7}{*}{$\begin{array}{l}\text { Physical } \\
\text { parameters }\end{array}$} & \multirow[t]{4}{*}{$\mathrm{pH}$} & Strongly acidic $(<4.5)$ & 7.85 & 0.01 & & 0.00 & 0.51 & 0.00 \\
\hline & & $\begin{array}{l}\text { Moderately acidic (4.5- } \\
5.5)\end{array}$ & 25554.33 & 38.78 & 14951.90 & 21.16 & 21358.58 & 21.49 \\
\hline & & Slightly acidic $(>5.5-6.5)$ & 37152.00 & 56.38 & 52947.73 & 74.93 & 72404.96 & 72.85 \\
\hline & & Normal $(>6.5-7.3)$ & 3185.66 & 4.83 & 2766.32 & 3.91 & 5618.47 & 5.65 \\
\hline & \multirow[t]{3}{*}{$\mathrm{OC}(\%)$} & Low $(<0.50)$ & 106.77 & 0.16 & 62.40 & 0.09 & 59.85 & 0.06 \\
\hline & & Medium $(0.50-0.75)$ & 1570.68 & 2.38 & 279.05 & 0.39 & 128.15 & 0.13 \\
\hline & & High $(>0.75)$ & 64222.39 & 97.45 & 70324.50 & 99.52 & 99194.52 & 99.81 \\
\hline \multirow{6}{*}{$\begin{array}{l}\text { Macro- } \\
\text { nutrients }\end{array}$} & \multirow[t]{3}{*}{$\mathrm{P}(\mathrm{kg} / \mathrm{ha})$} & Low $(<10)$ & 8014.92 & 12.16 & 5038.89 & 7.13 & 15036.08 & 15.13 \\
\hline & & Medium (10-25) & 52853.49 & 80.20 & 50960.87 & 72.12 & 70627.65 & 71.07 \\
\hline & & High $(>25)$ & 5031.43 & 7.63 & 14666.19 & 20.75 & 13718.78 & 13.80 \\
\hline & \multirow[t]{3}{*}{$\mathrm{K}(\mathrm{kg} / \mathrm{ha})$} & Low $(<120)$ & 9297.60 & 14.11 & 7661.85 & 10.84 & 15123.81 & 15.22 \\
\hline & & Medium (120-280) & 43205.99 & 65.56 & 44927.59 & 63.58 & 68753.40 & 69.18 \\
\hline & & High (>280) & 13396.25 & 20.33 & 18076.52 & 25.58 & 15505.31 & 15.60 \\
\hline \multirow{8}{*}{$\begin{array}{l}\text { Micro } \\
\text { nutrients }\end{array}$} & \multirow[t]{2}{*}{$\mathrm{Zn}(\mathrm{ppm})$} & Deficient $(<0.6)$ & 7940.66 & 12.05 & 4139.76 & 5.86 & 24448.60 & 24.60 \\
\hline & & Sufficient $(>0.6)$ & 57959.18 & 87.95 & 66526.19 & 94.14 & 74933.92 & 75.40 \\
\hline & \multirow[t]{2}{*}{$\mathrm{Fe}(\mathrm{ppm})$} & Deficient $(<4.5)$ & 448.73 & 0.68 & 140.49 & 0.20 & 23.05 & 0.02 \\
\hline & & Sufficient $(>4.5)$ & 65451.11 & 99.32 & 70525.46 & 99.80 & 99359.47 & 99.98 \\
\hline & \multirow[t]{2}{*}{$\mathrm{Cu}(\mathrm{ppm})$} & Deficient $(<0.2)$ & 1795.47 & 2.72 & 98.51 & 0.14 & 512.30 & 0.52 \\
\hline & & Sufficient $(>0.2)$ & 64104.37 & 97.28 & 70567.44 & 99.86 & 98870.22 & 99.48 \\
\hline & \multirow[t]{2}{*}{$\mathrm{Mn}(\mathrm{ppm})$} & Deficient $(<2.0)$ & 3212.42 & 4.87 & 1570.69 & 2.22 & 9503.95 & 9.56 \\
\hline & & Sufficient $(>2.0)$ & 62687.42 & 95.13 & 69095.27 & 97.78 & 89878.57 & 90.44 \\
\hline
\end{tabular}




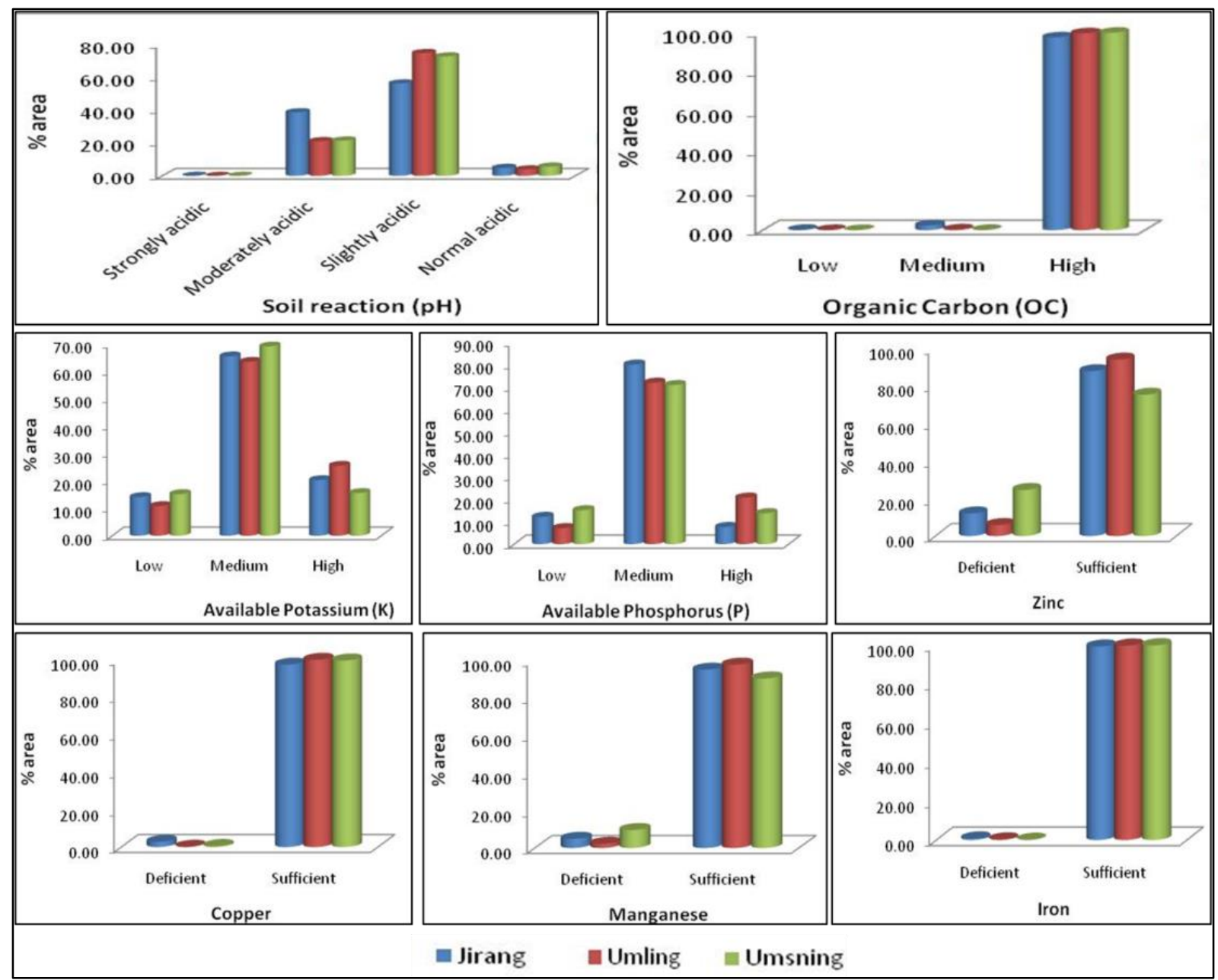

Fig-3: Block wise spatial distribution of $\mathrm{pH}, \mathrm{OC}$, available $\mathrm{P}, \mathrm{K}$ and micro nutrient classes

\section{CONCLUSION}

The study gives an example that soil health card data can be utilized for preparation of soil fertility map by using geospatial technology. The study revealed that soils of Ri Bhoi district is non saline and slightly to moderately acidic in reaction with high in organic carbon content. It is also found soils of the district are mostly medium in available phosphorus and potassium and sufficient in micronutrient contents.

\section{ACKNOWLEDGEMENTS}

The authors would like to thank Directorate of Agriculture, Govt. of Meghalaya and Ministry of Agriculture, Govt. of India for funding of the project and also for providing necessary support during project formulation and map finalisation.

\section{REFERENCES}

1. Khadka, D., Lamichhane, S., Amgain, R., Joshi, S., Vista Shree, P., Sah, K., \& Ghimire Netra, H. (2019). Soil fertility assessment and mapping spatial distribution of Agricultural Research Station, Bijayanagar, Jumla, Nepal. Eurasian J Soil Sci, 8(3):237-248.
2. Panda, S. C. (2010). Soil Management and Organic Farming. Agrobios, Bharat Printing Press, Jodhpur, India. 462.

3. Cambardella, C. A., \& Karlen, D. L. (1999). Spatial analysis of soil fertility parameters. Precision Agriculture. 1(1): 5-14.

4. Mishra, A., Das, D., \& Saren, S. (2013). Preparation of GPS and GIS based soil fertility maps for Khurda district, Odisha. Indian Agriculturist, 57(1): 11-20.

5. Mandal, A. K., \& Sharma, R. C. 2009. Computerized database of salt affected soils for Peninsular India using GIS. Geocarto International. 24(1):64-85.

6. Singh, G., Kumar, B., \& Shashikant. (2018). Soil Fertility Mapping Using Remote Sensing and GIS in NSP Farms of ND University of Agriculture and Technology, Kumarganj, Faizabad, Uttar Pradesh, India. Int J Curr Microbiol App Sci, 7: 1394-1402.

7. Ravikumar, M. A., Patil, P. L., \& Dasog, G. S. (2004). Characterization and mapping of soil resources of 48A distributaries of Malaprabha right bank command, Karnataka for land use planning. Karnataka Journal of Agricultural Sciences, 22, 81-88. 
8. Huang, B., Sun, W., Zhao, Y., Zhu, J., Yang, R., Zou, Z., Ding, F., \& Su, J. (2007). Temporal and spatial variability of soil organic matter and total nitrogen in an agricultural ecosystem as affected by farming practices. Geoderma, 139(3-4):336345 .

9. Weindorf, D. C., \& Zhu, Y. (2010). Spatial variability of soil properties at Capulin volcano, New Mexico, USA: Implications for sampling strategy. Pedosphere, 20(2): 185-197.

10. Liu, Z. P., Shao, M. A., \& Wang, Y. Q. (2013). Spatial patterns of soil total nitrogen and soil total phosphorus across the entire Loess Plateau region of China. Geoderma. 197-198: 67-78.

11. Prabhavati, K., Dasog, G. S., Patil, P. L., Sahrawat, K. L., \& Wani1, S. P. (2015). Soil
Fertility Mapping using GIS in Three Agroclimatic Zones of Belgaum District, Karnataka Journal of the Indian Society of Soil Science, 63(2), 173-180.

12. Bandyopadhyay, S., Ray, P., Padua, S., Ramachandran, S., Jena, R. K., Roy, P. D., ... \& Ray, S. K. (2018). Priority Zoning of Available Micronutrients in the Soils of Agro-ecological Sub-regions of North-East India Using Geo-spatial Techniques. Agricultural research, 7(2), 200-214.

13. Iftikar, W., Chattopadhayaya, G. N., Majumdar, K., \& Sulewski, G. D. (2010). Use of village-level soil fertility maps as a fertilizer decision support tool in the red and lateritic soil zone of India. Better Crops, 94:10-12. 